\title{
Influence of elevations on woody tree species diversity in Nam Kar Natural Reserve of Daklak province, Vietnam
}

\author{
Anh hưởng độ cao đến đa dạng thực vật thân gỗ tại khu bảo tồn thiên nhiên \\ Nam Kar, tỉnh Đăklăk, Việt Nam \\ Research article
}

Nguyen, Thi Thanh Huong*; Chau, Thị Nhu Quynh

Department of Forest resource \& Environment management (Frem), Faculty of Agriculture and Forestry, Tay Nguyen University, Le Duan Str. 567, Buon Ma Thuot City, Daklak Province, Vietnam

This paper describes the influence of elevation on woody tree species diversity in Nam Kar Natural Reserve of Daklak, of which remote sensing and GIS techniques were used as the tools in biodiversity inventory and assessment. The whole Reserve area was divided into four elevation classes based on DEM (Digital Elevation Model) using GIS technique. Landsat 8 satellite image was employed to stratify the forest into the four strata. A total of 4 transect lines of $100 \mathrm{~m}$ in length and $20 \mathrm{~m}$ in width (abbreviated as H1, H2, H3, and H4) established in east-west direction representing for 4 elevation classes was used for surveying biodiversity and stand structure. The different diversity indices were compared among the different elevation classes. The relationships between reflectance value of satellite image, forest strata with biodiversity indices were also analysed. The result shows that the diversity of woody tree species is different among elevation classes. Based on sample plots a total of 135 tree species belonging to 42 genera was found in this area. Although a low inverse correlations were found between number of species composition, basal area, and tree density with DNs, most correlation was statistically insignificant $95 \%$. However, a medium relation between forest strata and number of species composition were found with correlation coefficient $\mathrm{r}=0.53(\mathrm{P}<0.00)$ in the area.

Nghiên cưu này đánh giá đa dạng thực vật thân gỗ tại khu bảo tồn thiên nhiên Nam Kar theo các cấp độ cao khác nhau. Nghiên cứu đã sử dụng ảnh vệ tinh và kỹ thuạt GIS để hố trong trong việc điều tra và đánh giá đa dạng sinh học. Toàn bộ khu bảo tồn được chia thành 4 cấp độ cao dụa vào mô hình số độ cao (DEM) được thực hiện bằng kỹ thuật GIS. Ảnh Landsat 8 đã được sủ dụng để phân chia rùng thành 4 khối trạng thái. Có 4 ô tiêu chuẩn dạng dải có kích thuớc $100 \mathrm{~m}$ chiều dài và $20 \mathrm{~m}$ chiều rộng được đặt ở tù̀ng đai cao (viết tắt là $\mathrm{H1}, \mathrm{H2}, \mathrm{H3}$, và H4) theo huớng cố định Đông - Tây để điều tra đa dạng sinh học và cấu trúc lâm phần của thực vật thân gố ở tùng đai cao. Các chỉ số đa dạng sinh học đã được so sánh trong tùng cấp độ cao. Mối quan hệ giũa giá trị ảnh, hiện trạng rùng với các chỉ số đa dạng cũng được phân tích. Kết quả nghiên cứu cho thấy có sự khác biệt về đa dạng loài thục vật thân gố theo tùng đai cao. Dựa vào ô mẫu nghiên cúu cũng đã uớc tính có 135 loài thuộc 42 chi có trong vùng nghiên cưu. Một số đặc điểm lâm phần nhu thành phần loài, tiết diệt ngang bình quân và mật độ cây có mối tuơng quan nghịch với giá trị ảnh vệ tinh tuy nhiên mối quan hệ này không có ý nghĩa thống kê ở độ tin cậy 95\%. Tuy vậy nghiên cứu cho thấy có mối tương quan tương quan khá chặt giữa số loài và các khối hiện trạng rùng với hệ số tương quan là 0.53 ở múc $P<0.00$.

Keywords: Remote Sensing, GIS, biodiversity, woody tree species 


\section{Introduction}

Biodiversity is defined as the abundance of genetic resources, species and ecosystems in nature (Biodiversity Law of Vietnam, 2008). The tropical forests with the most diversity of species have been lost and are increasingly degraded related to global climate change. The current situation shows that the conservation of ecosystems, including forest resources, biodiversity and prevention of the extinction of endangered species are urgent tasks. Information on species composition, diversity of tree species is of primary importance in the planning and implementation of biodiversity conservation efforts. Development of sustainable forest management and conservation strategies requires an understanding of changes e.g. composition and structure of tropical forest following different disturbance regimes, status of species distribution in spatial scales.

The diversity of geographical conditions produces a wide variety of ecosystems in the Central Highlands of Vietnam, making this region of richest biodiversity in Vietnam. Daklak is one of provinces belonging to the Central Highlands also considered as the highest biodiversity with many endemic species. Elevation is one of the two environment gradients representing a broad range of climatic and edaphic site condition. Hence some studies focused on this aspect such as Keever (1953) Whittaker (1956), Johnson and Ware (1982), Whitney and Johnson (1984). The results of these studies revealed that there is a relation between elevation and variation in species distribution.

In recent years, the numerous studies proved that remote sensing and GIS techniques provides a useful approach for supporting in inventory of biodiversity. These studies have integrated remote sensing data along with a variety of methods to quantify biodiversity as well as find out the relationship between remote sensing data and species index. Many studies used GIS and remote sensing to map habitats and used the data as tools for monitoring and assessing biodiversity e.g. Debinski et al. (1998); Kiran and Mudaliar (2012), Jha et al. (2005). Especially, the relations between remotely sensed data and species distribution patterns were explored. Rocchini et al (2007) used compression techniques, such as Principal Component Analysis (PCA) to find out relationship between spectral heterogeneity and species richness and evaluated which spectral interval is the most adequate for predicting species richness by means of linear regression. The result confirmed the potential of satellite data for estimating species richness is likely to be due to the near infrared bands, rather than to the visible bands, which share highly redundant information. John et al. (2008) predicted species richness using RS for monitoring distribution. The result indicated the high potential for estimating plant biodiversity based on RS.

The research and application of GIS and remote sensing techniques in the investigation of biodiversity in Vietnam has still limited. There is no any analysis of the relationship between satellite imagery and species indices done. Moreover, there has not evaluated relationship between characteristics of woody tree species with levels of elevation.

\section{Materials and methodology}

\subsection{Study area and data}

This study was performed in Nam Kar Nature Reserve (NR) of Daklak province. The site study covers $12^{\circ} 15^{\prime} 34^{\prime \prime}$ - 12 $26^{\circ} 24^{\prime \prime}$ latitude North and 107 $55^{\prime} 13^{\prime \prime}$ - 108 $07^{\prime} 36^{\prime \prime \prime}$ longitude East. This is one of the most important natural forest of the Central Highland. The elevation varies from $430-1294 m$ with complex terrain, steep slopes. This lead to a diversity of plant communities in environment conditions. Terrain Nam Kar NR is quite complex, ranging from $400-1250 \mathrm{~m}$, the highest peak is of $1294 \mathrm{~m}$ high, namely Chu Nam Kar. The lowest foothill is Ea Bo Nie Lake that is located in the northwest of the region, with elevation above sea level in $418 \mathrm{~m}$. The highest change of elevation is the southeast part of the Reserve, ranging from $500 \mathrm{~m}$ to $1250 \mathrm{~m}$. A steep slope is seen in this area with continuous changing in the length ridge. The complex differentiation of elevations may lead diversity of plant communities in spatial in this area. The region with high variation elevations were selected in the present study in order to classify into 4 levels of elevation, including $500-700 \mathrm{~m}$ (H1); 700 $-850 \mathrm{~m}(\mathrm{H} 2) ; 850-1000 \mathrm{~m}(\mathrm{H} 3)$ and more than $1000 \mathrm{~m}$ (H4). The map of elevation class is shown in Figure 1.

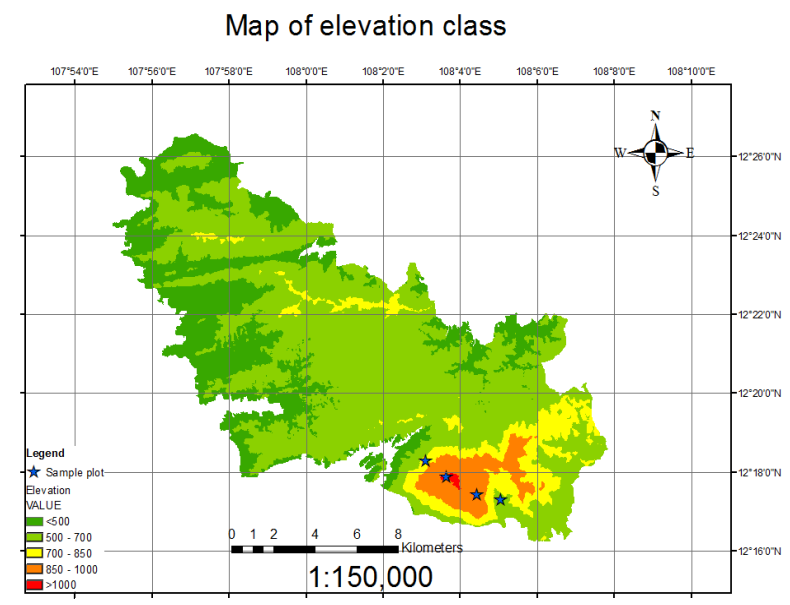

Figure 1. Classified elevation of study site

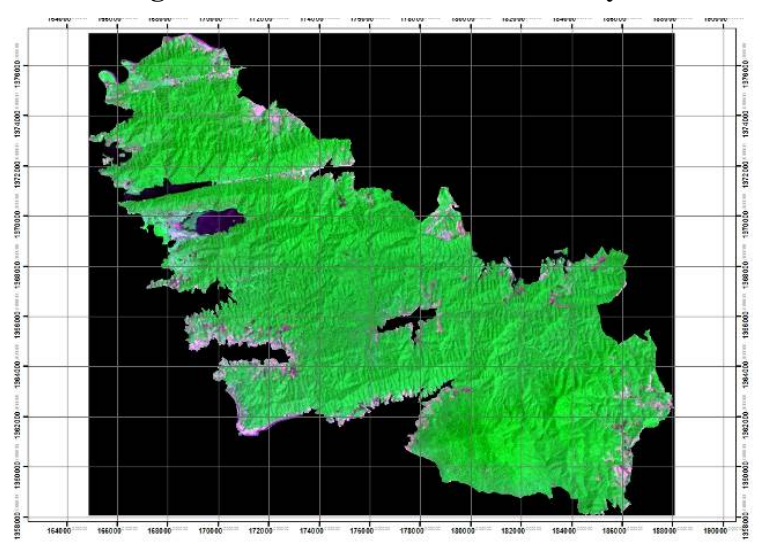

Figure 2. Landsat image subseted by Nam Kar NR border

\subsection{Remotely sensed data processing}

The Landsat 8 captured in February 2016 was used in this study. The general information of the Landsat 8 was shown in Table 1. Because of purpose of forest cover classification, only seven bands from band 2 to band 7 of OLI were 
used to stratify the forest into homogeneous units. The Landsat image was subseted based on the border of Nam Kar NR as shown in Figure 2. The stratification of the forest was carried using supervised classification algorithm of Maximum likelihood based on training sites collected in the field, existing data (e.g. forest maps), and prior knowledge on study site. One part of the field data was used to select training areas for the supervised maximum likelihood classification process, the other part was employed as independent reference data for accuracy assessment of the classification. The forest map was then compiled using QGIS software.

Table 1. Wavelength range and spatial resolution of the Landsat 8 OLI and TIRS

\begin{tabular}{lrr} 
Band & Wavelength Range $(\boldsymbol{\mu m})$ & Spatial Resolution $(\mathbf{m})$ \\
\hline OLI 1 & $0.433 \sim 0.453($ coastal/aerosol) & 30 \\
OLI 2 & $0.450 \sim 0.515$ (blue) & 30 \\
OLI 3 & $0.525 \sim 0.600$ (green) & 30 \\
OLI 4 & $0.630 \sim 0.680$ (red) & 30 \\
OLI 5 & $0.845 \sim 0.885$ (Near-IR) & 30 \\
OLI 6 & $1.560 \sim 1.600$ (SWIR-1) & 30 \\
OLI 7 & $2.100 \sim 2.300$ (SWIR-2) \\
OLI 8 & $0.500 \sim 0.680$ (pan) & 30 \\
OLI 9 & $1.360 \sim 1.390$ (Cirrus) \\
TIRS 10 & $10.30 \sim 11.30$ (LWIR-1) & 15 \\
TIRS 11 & $11.50 \sim 12.50$ (LWIR-2) & 30 \\
\end{tabular}

\subsection{Sampling design and data collection}

A DEM with resolution of $30 \mathrm{~m} \times 30 \mathrm{~m}$ was conducted from topographic map at scale 1:50000. The DEM was used to locate the existing forest trails and baselines in the forest area. A total of four transect lines of $100 \mathrm{~m}$ in length and $20 \mathrm{~m}$ in width (abbreviated as H1, H2, H3, and H4) were established in east-west direction using a compass. The different class of elevation is described in Table 2. Each transect line was gridded into five plots, each $20 \mathrm{~m} \times$
$20 \mathrm{~m}$ in size, as workable units. Within the plot all trees with a diameter at breast height (DBH, $1.3 \mathrm{~m}$ above the ground) above $6 \mathrm{~cm}$ were measured and identified by species. The DBH was measured using a DBH tape. The central position of subplot $(20 \times 20 \mathrm{~m})$ was recorded using GPS 62 CXS. Corresponding to the sample plots as described above, the average values of pixel (digital number) of the bands of Landsat 8 satellite image were also calculated.

Table 2. General features of sample plot within the four transect lines of the study area

\begin{tabular}{lllc} 
Elevation class & No. of plot & Area $\left(\mathbf{m}^{\mathbf{2}}\right)$ & Range of elevation class $(\mathbf{m})$ \\
\hline H1 & 5 & $20 \times 20$ & $500-700 \mathrm{~m}$ \\
H2 & 5 & $20 \times 20$ & $700-850 \mathrm{~m}$ \\
H3 & 5 & $20 \times 20$ & $850-1000 \mathrm{~m}$ \\
H4 & 5 & $20 x 20$ & $>1000$
\end{tabular}

\subsection{Data analysis}

The means of basal area, genera, species and tree density per hectare were calculated for each transect line. The relative dominance of species in each transect line was identified on the basis of relative basal area. The basal area (BA) was calculated in equation below:

$$
B A=\pi r^{2}=3.142 x\left(\frac{D B H}{200}\right)^{2}
$$

Where $\mathrm{BA}=$ tree basal area $(\mathrm{m} 2) ; \mathrm{r}=\operatorname{radius}(\mathrm{cm})$

The relative basal area of a species on transect lines was calculated as the basal area of a species divided by total basal area of the site and multiplied with 100 . The dominant and co-dominant species of each site were identified based on this value. The species with the highest relative basal area was defined as dominant and that with the second highest relative basal area was defined as co-dominant.

\subsection{Calculation of species diversity indices}

A variety of different diversity indices were calculated for ach transect as well as pooled data for all transects.

- Shannon diversity index (H') (Shannon and Weiner, 1949) is calculated using the following equation:

$$
H^{\prime}=\sum_{i=1}^{s} p i l n p i
$$

Where

$H^{\prime}=$ the Shannon index

$p i=$ the proportion of individuals belonging to species

$\ln =$ the natural $\log ($ i.e., 2.718$)$

- $\quad$ The species richness SR (number of species per unit area) was calculated using Margalef index of species richness (Margalef, 1958) as follows: 


$$
\mathrm{SR}=\frac{S-1}{\ln (N)}
$$

Where

SR: the Margalef index of species richness $S$ : the number of species

- The Whittaker's index of $\beta$-diversity $\beta \mathrm{w}$ (Whittaker, 1972) was calculated using the following equation:

$$
\beta w=\frac{S_{c}}{\bar{S}}
$$

Where

$\beta \mathrm{w}=$ the Whittaker's index of $\beta$-diversity

$\mathrm{Sc}=$ the total number of species $\mathrm{S}=$ the average number of species per sample

- Simpson's diversity (D) (Simpson, 1949) was calculated using the following equation:

$$
1-D=1-\sum_{i}^{s}[p i]^{2}
$$

Where

$\mathrm{D}=$ the Simpson diversity

$\lambda=$ the Simpson's concentration of dominance calculated as $\sum$ pi2

- The Whittaker's index of species evenness Ew (Whittaker, 1972) was calculated using the following equation:

$$
E_{w}=\frac{S}{\ln N_{i}-\ln N_{s}}
$$

Where

Ew=the Whittaker's index of evenness

$\mathrm{Ni}=$ the abundance of most important species

$\mathrm{Ns}=$ the abundance of the least important species

- Bray-Curtis index $\left(\mathrm{C}_{\mathrm{N}}\right)$ (Bray and Curtis, 1947), a similarity coefficient, is used to measure similarity between transect lines.

$$
C_{N}=\frac{2 j N}{(a N+b N)}
$$

Where

$\mathrm{CN}=$ the Bray-Curtis index

$\mathrm{aN}=$ individual numbers of plot $\mathrm{A}$

$\mathrm{bN}=$ individual numbers of plot $\mathrm{B}$

$\mathrm{jN}=$ the sum of less individual numbers of each species common in plots $\mathrm{A}$ and $\mathrm{B}$

\section{Results}

\subsection{Stratify the forests into homogenous clas- ses}

The forest in the Reserve was discriminated into 4 classes with overall classification accuracy to be of $88 \%$. Comparing to the filed data along with visual observation on the image with prior knowledge, the distinguished classes were determined as dense, moderate, open, and regeneration forest. From the classified result, the forest map was produced using software of QGIS. The area of land cover was provided in Table 3 and the forest map was illustrated in Figure 3.

Table 3. The area of land cover in Nam Kar NR

Land cover (ha)

Dense forest

Moderate forest

Open forest

Regeneration forest

Bamboo

Agricultural land

Water body

Total
Area (Ha)

672.1

4280.9

4746.7

1239.9

2786.8

6930.8

228.7

20885.9
Rate (\%) 


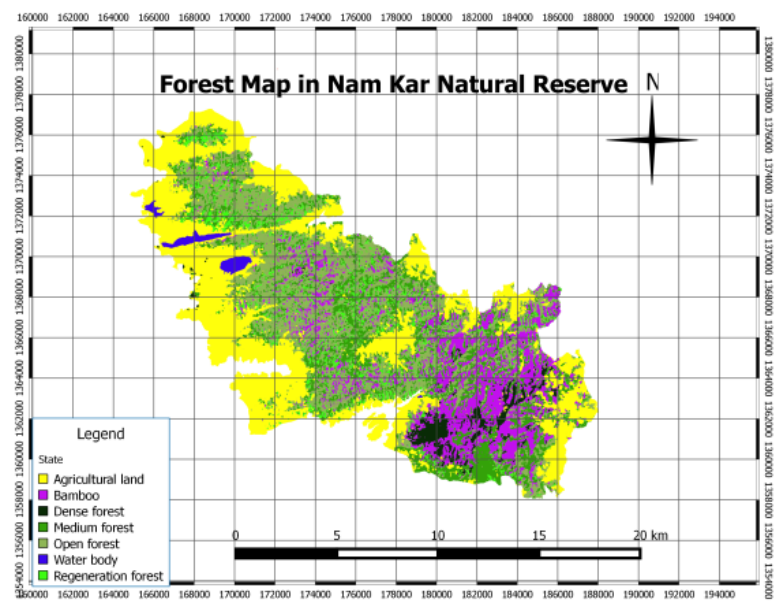

Figure 3. Forest maps of Nam Kar NR

Results showed that forest area is large with 10939.6 ha, corresponding $65 \%$, of which the medium and open forests cover 9027.6 ha with nearly 20 and $22 \%$, respectively; rich forests account for only 672 ha corresponding with $3.22 \%$. The other lands including agricultural land, bamboo and water body are nearly $35 \%$. The high forest cover may be due to i) this is the natural reserve, therefore, the forest has been well managed; and ii) complex terrain leads to the difficulty in accessing to the forest.

\subsection{Analysis of characteristics, structure and plant diversity by elevation levels}

\subsubsection{Analysis of characteristics of forest stand struc- ture}

Information on basal area, tree density, species and genera densities are effective description for forest stand structure and spatial distribution of forest trees present in the landscape. These four parameters are presented in Table 4.

Table 4. The stand structure of Nam Kar NR

\begin{tabular}{|c|c|c|c|c|}
\hline Variables & H1 & $\mathbf{H 2}$ & H3 & H4 \\
\hline Mean basal area $(\mathrm{BA})\left(\mathrm{m}^{2} / \mathrm{ha}^{-1}\right)$ & 47.84 & 38.66 & 32.82 & 42.09 \\
\hline Mean tree density ha ${ }^{-1}$ & 1040 & 920 & 1110 & 990 \\
\hline No. of species & 35 & 55 & 77 & 57 \\
\hline No. of genera & 42 & 35 & 34 & 25 \\
\hline
\end{tabular}

The density and size distribution of trees contribute to the structure characteristics of tropical forests. Typically, the variation of tree density depends on various factors such as ecology, human activities. From the table above shows the means basal area per hectare on different transects varied from $32.82 \mathrm{~m}^{2} \mathrm{ha}^{-1}$ (H3) to $47.84 \mathrm{~m}^{2} \mathrm{ha}^{-1}$ (H1). It is easy to recognise the BA decreases from altitudes of $500-700 \mathrm{~m}$ to altitudes of $850-1000 \mathrm{~m}$. The higher elevation is the more abundance of species is found. This may be due to different degrees of human disturbance. Although number of species was different among the height levels, a total of 135 species belong to 42 genera was found in the plots. The species composition and density from $6 \mathrm{~cm}$ in diameter ranges from 35 species (H1) to 77 species (H3) and 920 trees $\mathrm{ha}^{-1}(\mathrm{H} 2)$ to 1040 trees $\mathrm{ha}^{-1}(\mathrm{H} 1)$ respectively. This indicates the natural distribution of species and individuals in the higher elevations of the tropical forest. According to Richards (1952) factors affecting the tree density are usually natural factors, anthropogenic disturbance, and soil conditions. The number of species increases from low to high elevation, but to a certain threshold, then dropped (e.g. $1000 \mathrm{~m}$ ). Results also showed that the number of woody tree genera decreased by elevation. In this cases the genera vary from 42 genera at $\mathrm{H} 1$ to 25 genera at $\mathrm{H} 4$. Tree species composition in tropical areas varies greatly from one place to another mainly due to variation in biogeography, habitat and disturbance (Whitmore, 1998). According Withmore (1982) the tree species per ha in tropical forests ranges from about 20 to a maximum of 223 (tree species were collected in $\mathrm{DBH}>10 \mathrm{~cm}$ ), however the study of Nwoboshi (1982) showed that the number of species in the very rich rainforest could be as high as 400 species ha ${ }^{-1}$. In this study, the highest number of species are at elevations of $\mathrm{H} 3$ with 385 . Therefore, the site study area is also considered as rich in species composition.

\subsubsection{Analysis tree species density}

The understanding of the diversity of Nam Kar NR was conducted by evaluating and comparing different diversity indices. Table 5 has generated interesting results on the species distribution pattern of this forest community. Results of field surveys reported the four transect lines with 20 sample plots had a total of 812 stems and 136 species of trees ( $>6 \mathrm{~cm} \mathrm{DBH})$. They belong to 42 genera, number of species varies from 35 species $(\mathrm{H} 1)$ to 77 species $(\mathrm{H} 3)$ and the number of individuals varies from 184 trees (H3) to 222 trees (H1). Table 5 summarizes the various diversity indices by elevation based on the field data inventoried.

Shanon index $\left(\mathrm{H}^{\prime}\right)$ was used to compare species diversity among the various levels of elevation. The highest H' was found in $\mathrm{H} 3$ with 5.07. H' increases from $\mathrm{H} 1$ to $\mathrm{H} 3$. The most complex species composition was presented in $\mathrm{H} 3$, whereas the simplest was H1 and H4. Similar patterns were found for species richness, which was computed using Margalef index (d) of species richness (SR) ranged from $6.37(\mathrm{H} 1)$ to $14.07(\mathrm{H} 3)$. The lowest $\mathrm{d}$ was found in $\mathrm{H} 1$, proving a low $\mathrm{SR}$ in this elevation level, whereas $\mathrm{H} 2, \mathrm{H} 3$, and H4 indicated quite high SR, of which the H3 is the highest. In the present study, although Simpson's diversity (D) was not a very sensitive indicator of diversity comparing to others had somewhat similar values, the result was similar. Whittaker index of $\beta$-diversity $(\beta \mathrm{W})$ was used to compare habitat heterogeneity among transects. The highest index was by 3.86 in $\mathrm{H} 1$, the lowest was by 1.75 at $\mathrm{H} 3$. These above proved there is a heterogeneity of habitat of woody tree species between the elevations. 
Table 5. Exhibiting diversity Indices in different elevation class

\begin{tabular}{|c|c|c|c|c|}
\hline Variables & H1 & $\mathbf{H 2}$ & H3 & H4 \\
\hline Shannon - Weiner index (H') & 3.56 & 5.15 & 5.07 & 1.50 \\
\hline Margalef index (d) & 6.37 & 10.35 & 14.07 & 10.59 \\
\hline Simpson index (1-D) & 0.84 & 0.96 & 0.95 & 0.95 \\
\hline Whittaker index of $\beta$-diversity $(\beta \mathrm{W})$ & 3.86 & 2.45 & 1.75 & 2.37 \\
\hline The number of equally common species & 7.99 & 13.08 & 17.57 & 15.91 \\
\hline
\end{tabular}

\subsubsection{Analysis of similarity between the elevation classes}

The similarity between elevations was based on indicators of Bray - Curtis index $\left(\mathrm{C}_{\mathrm{N}}\right)$. The $\mathrm{C}_{\mathrm{N}}$ was calculated between the pair of elevation classes and abundance similarity matrix was constructed (Table 6) using Pearson analysis. Comparison of $\mathrm{C}_{\mathrm{N}}$ values among the four transects data indicates that $\mathrm{H} 3$ had positive correlation with $\mathrm{H} 1$ and $\mathrm{H} 2$ in term of species composition at $99 \%$ statistically significant. This indicates there is a similarity between $\mathrm{H} 3$ with
$\mathrm{H} 1$ and $\mathrm{H} 2$ in species composition. The Pearson analysis results also show $\mathrm{H} 1$ has no statistically significant correlation with $\mathrm{H} 2$ in term of the $\mathrm{C}_{\mathrm{N}}$, indicating two elevation classes is not similarity in species composition. The results also showed elevation class H4 is no statistically significant correlation with the other elevations on the species composition, thus, in more than $1000 \mathrm{~m}$ high in elevations, there is a difference in species composition with lower elevations.

Table 6. Pearson correlation of Bray-Curtis index

\begin{tabular}{lc} 
Elevation class & H1 \\
\hline H1 & $0.1527 \mathrm{~ns}$ \\
$\mathrm{H} 2$ & $0.3212^{* *}$ \\
$\mathrm{H} 3$ & $-0.0485 \mathrm{~ns}$ \\
$\mathrm{H} 4$ & \\
*, ** indicates $1 \%$ and $5 \%$ significant level, respectively and \\
3.3 Analysis of the relationship between satel- \\
lite data with species composition and forest \\
parameters
\end{tabular}

\section{$0.2942 * *$ \\ $0.0089 \mathrm{~ns}$}

$0.0355 \mathrm{~ns}$

$0.0355 \mathrm{~ns}$

The present study analysed relationship between the reflec-
tance of satellite image with species composition $(\mathrm{S})$ and
forest parameters (basal area - BA, tree density $-\mathrm{N}$ ); the
relationship between number of species and forest status
was also tested.

The present study analysed relationship between the reflec-
tance of satellite image with species composition $(\mathrm{S})$ and
forest parameters (basal area - BA, tree density $-\mathrm{N}$ ); the
relationship between number of species and forest status
was also tested.

The present study analysed relationship between the reflec-
tance of satellite image with species composition $(\mathrm{S})$ and
forest parameters (basal area - BA, tree density $-\mathrm{N}$ ); the
relationship between number of species and forest status
was also tested.

The present study analysed relationship between the reflec-
tance of satellite image with species composition $(\mathrm{S})$ and
forest parameters (basal area - BA, tree density $-\mathrm{N}$ ); the
relationship between number of species and forest status
was also tested.

The present study analysed relationship between the reflec-
tance of satellite image with species composition $(\mathrm{S})$ and
forest parameters (basal area - BA, tree density $-\mathrm{N}$ ); the
relationship between number of species and forest status
was also tested.

\subsection{Analysis of the relationship between satel- parameters} not applied in this case.

\subsubsection{Correlation analysis of digital number of image and species composition and forest parameters}

The correlation analysis result in Table 7 provides a summary of the relationship between individual bands and $\mathrm{S}$, BA, and N. Most bands had a negative correlation with species composition and forest parameters except for band 7 (B7). Most correlation was not statistically significant with 95\%. Since an effective regression model for prediction cannot be derived if no correlation exists, regression was

Table 7. Pearson correlation matrix for the variables analysed for Species composition and forest parameters

\begin{tabular}{lllllll} 
& B2 & B3 & B4 & B5 & B6 & B7 \\
\hline S & $-0,188 n \mathrm{~ns}$ & $0,020 \mathrm{~ns}$ & $-0,264 \mathrm{~ns}$ & $-0,277 \mathrm{~ns}$ & $-0,277 \mathrm{~ns}$ & $0,274 \mathrm{~ns}$ \\
BA & $0,094 \mathrm{~ns}$ & $0,392 \mathrm{~ns}$ & $-0,136 \mathrm{~ns}$ & $-0,238 \mathrm{~ns}$ & $-0,271 \mathrm{~ns}$ & $0,201 \mathrm{~ns}$ \\
N & $-0,141 \mathrm{~ns}$ & $-0,062 \mathrm{~ns}$ & $-0,145 \mathrm{~ns}$ & $-0,134 \mathrm{~ns}$ & $-0,128 \mathrm{~ns}$ & $0,139 \mathrm{~ns}$
\end{tabular}

*,** indicates $1 \%$ and $5 \%$ significant level, respectively and ns means insignificant

\subsubsection{Correlation analysis of forest class and species composition and forest parameters}

The relationship between species composition and reflectance responses was developed using the correlation of tree species composition with forest classes. Prior to commencing the correlation analysis, the classes of forest were coded from 1 to 4 (1: Dense forest, 2: Moderate forest, 3: open forest and 4: Regeneration forest). The sample plots were overlaid on the forest classes in order to identify species composition presenting on each forest class. The result of the statistics process with involved variables shows that all variables came from a normal distribution. The selective principle of the model is based on the coefficient of determination $\mathrm{R}^{2}$ (or correlation coefficient) at statistical significance. Given a range of candidate models, the output is the result of fitting a single regression model to represent the relationship between species composition and forest classes described in the equation below:

$$
\begin{gathered}
S=1.21429+6.47619 * \text { forest class } \\
P<0.00, R 2=0.29, R=0.53
\end{gathered}
$$


The obtained model had a moderate relationship implied by the adjusted coefficient of determination of 0.29 equivalent to the correlation coefficient $r=0.53$. The parameters of candidate variable were statistically significant. The result shows that there is potential to apply remote sensing data in biodiversity inventory and monitoring.

\section{Conclusions}

The study area indicates there is abundance of species composition and number of tree species in Nam Kar NR with 135 species belonging to 42 genera. Analysis of diversity indices of woody tree species following elevation ranges indicates there is a difference of species diversity among elevation levels. The most complex in species composition was found in elevation range of $700-1000$ $\mathrm{m}$. The elevations of $\mathrm{H} 4(>1000 \mathrm{~m})$ is the simplest composition but more dissimilarity comparing to lower elevations. There had not found a significant correlation of species composition with almost all bands. The relationship between the number of woody species with forest status which categorized from satellite image was detected to be correlated at a statistically significant at $95 \%$ confident level. This indicates the richer forest is present, the more number of woody tree species exists in this area.

\section{References}

[1] Bray, J. R. and J. T. Curtis. 1957. An ordination of the upland forest communities of southern Wisconsin. Ecol. Monogr. 27, 325-49.

[2] Biodiversity Law, 2008. No. 20/2008/QH12. Socialist Republic of Vietnam. (http://thuvienphapluat.vn/van-ban/Tai-nguyen-Moi-truong/Luat-dadang-sinh-hoc-2008-20-2008-QH12-82200.aspx).

[3] Debinski, D. M., Kindscher, K. and Jakubauskas, M.E. (1999). A remote sensing and GIS-based model of habitats and biodiversity in the Greater Yellowstone Ecosystem. int. j. remote sensing, 1999, vol. 20, no. 17, 3281- 3291. Taylor and Francis.

[4] Jha, C.S., Goparaju, L, Tripathi, A., Gharai, B., Raghubanshi, A.S., and Singh J.S. 2005. Forest fragmentation and its impact on species diversity: an analysis using remote sensing and GIS. Biodiversity and Conservation14:1681-1698, 2005. Springer.

[5] John, R., Chen, J., Lu, N., Guo, K., Liang, C., Wei,
Y., Noormets , A., Ma, K., Han , P.X. 2008. Predicting plant diversity based on remote sensing products in the semi-arid region of Inner Mongolia. Remote Sensing of Environment 112 (2008) 2018-2032.

[6] Johnson, G. G., and Were, S. 1982. Post chestnut forests in the central Blue Ridge of Virginia. Castanea 47:329-343.

[7] Keever, C. 1953. Present symposition of some stands of former oak-chestnut forest in the southern Blue Ridge mountains. Ecology 34: 44-54.

[8] Kiran, G. S. and Mudaliar, A. (2012). Remote sensing \& Geo-informatics technology in evaluation of forest tree diversity. Pelagia Research Library Asian Journal of Plant Science and Research, 2012, 2 (3):237-242.

[9] Margalef, F. R. 1958. Information theory in ecology. Gen. Syst., 3:36-71.

[10] Richards, P. W. 1952. The Tropical Rain Forest, Cambridge University Press.

[11] Rocchini, D., Ricotta, C., \& Chiarucci, A. 2007. Using satellite imagery to assess plant species richness: The role of multispectral systems. Applied Vegetation Science 10: 325-332, 2007 (C) IAVS; Opulus Press Uppsala.

[12] Shannon, C. E. and W. Weiner, 1949. The Mathematical Theory of Communication. University of Illinois Press, Urbana, USA.

[13] Simpson, E. H. 1949. Measurement of diversity. Nature, 163: 688. University of Illinois Press, Urbana, USA.

[14] Whitmore, T. C. 1998. An Introduction to Tropical Forests, Clarendon Press, Oxford and University of Illinois Press, Urbana, 2nd, Ed. pp. 117.

[15] Whitmore, T.C. 1984. Tropical Rain Forests of the Far East. Clarendon Press, Oxford.

[16] Whitney, H. E. and Johnson, W. C. 1984. Ice storm and forest succession in southwestern Virginia. Bulletin of the Torrey Botanial Club 111:429-437.

[17] Whittaker, R. H. 1972. Evolution and measurements of species diversity. Taxon, 21: 213-251.

[18] Whittaker, R.H. 1956. Vegetation of the Great Smoky Mountains. Ecological Monographs 26: 1-80. 